\title{
PERAN BRAND AWARENESS MEMEDIASI PENGARUH SOCIAL MEDIA MARKETING TERHADAP PURCHASE INTENTION
}

\author{
Ni Made Ayu Sutariningsih 1 \\ I Gusti Ngurah Jaya Agung Widagda $\mathrm{K}^{2}$
}

\author{
1,2 Fakultas Ekonomi dan Bisnis Universitas Udayana (Unud), Bali, Indonesia \\ email : ayusutariningsih@gmail.com
}

\begin{abstract}
ABSTRAK
Perkembangan teknologi di era globalisasi ini sangat pesat. Social media marketing penting bagi strategi pemasaran. Social media marketing harus dilakukan dengan kreatif dan menarik untuk membentuk brand awareness sehingga dapat meningkatkan purchase intention. Studi ini bertujuan untuk menjelaskan peran brand awareness memediasi pengaruh social media marketing terhadap purchase intention. Obyek penelitian adalah produk Chatime di Kota Denpasar. Data dikumpulkan menggunakan kuisioner online dengan jumlah sampel sebanyak 120 responden. Metode penentuan sampel yang digunakan pada penelitian adalah non probability sampling yaitu teknik purposive sampling. Teknik analisis mengunakan analisis jalur (path analysis) dan uji sobel. Hasil penelitian ini menunjukan social media marketing berpengaruh positif dan signifikan terhadap purchase intention dan brand awareness; brand awareness berpengaruh positif dan signifikan terhadap purchase intention; brand awareness memediasi secara signifikan pengaruh social media marketing terhadap purchase intention. Perusahaan Chatime sebaiknya menambah fitur avatar, giveaway, quiz, voucher, fun fact dan bintang iklan, serta membuat iklan informatif dan iklan yang menarik seperti : pengunaan animasi, karakter, musik, dan gambar maupun font yang unik.

Kata kunci: social media marketing, brand awareness, purchase intention
\end{abstract}

\begin{abstract}
The development of technology in this era of globalization is very fast. Social media marketing is important for any marketing strategy. Social media marketing must be done creatively and attractively to form brand awareness so that it can increase purchase intention. This study aims to explain the role of brand awareness in mediating the influence of social media marketing on purchase intention. The research object is the Chatime product in Denpasar City. Data were collected using an online questionnaire with a total sample of 120 respondents. The sampling method used in the study was non-probability sampling, namely purposive sampling technique. The analysis technique uses path analysis and single test. The results of this study indicate that social media marketing has a positive and significant effect on purchase intention and brand awareness; brand awareness has a positive and significant effect on purchase intention; brand awareness significantly mediates the effect of social media marketing on purchase intention. The Chatime company should add features to avatars, giveaway, quizzes, vouchers, fun facts and advertising stars, as well as create informative advertisements and attractive advertisements such as: the use of animations, characters, music, and unique images and fonts.
\end{abstract}

Keywords : social media marketing, brand awareness, purchase intention 


\section{PENDAHULUAN}

Perkembangan teknologi di era globalisasi ini sangat pesat. Kini perkembangan teknologi sangat memudahkan masyarakat untuk memenuhi kebutuhannya. Salah satunya adalah berkomunikasi dan mendapat informasi. Dahulu, sebelum adanya perkembangan teknologi, informasi sangat sulit didapatkan komunikasi harus melalui surat ataupun dari mulut ke mulut sehingga mengakibatkan teknologi terus dikembangkan untuk mempermudah masyarakat berkomunikasi dan mendapatkan informasi secara luas. Salah satunya adalah internet, hampir seluruh masyarakat di berbagai negara membutuhkan internet untuk mempermudah berkomunikasi, mencari informasi, hiburan dan kebutuhan lainnya.

Kehadiran bubble drink ditengah masyarakat menjadi salah satu fenomena pertumbuhan minuman manis yang sangat pesat. Peluang pasar yang menjanjikan dan terus berkembang menarik bagi pebisnis. Salah satu Negara di Asia Tenggara yang masyarakatnya paling banyak mengonsumsi bubble drink adalah Indonesia. (Firdausya, 2019)

Kota Denpasar merupakan ibu kota dari Provinsi Bali. Kota Denpasar mengalami pertumbuhan yang sangat cepat baik dalam artian fisik, ekonomi maupun sosial budaya, begitupula kehidupan masyarakatnya telah menunjukan ciriciri dan sifat perkotaan (Denpasar, 2019). Selain itu, Kota Denpasar adalah kota yang meraih penghargaan Best City Smart Economy pada tahun 2019 dengan transformasi digital (Statistika, 2019). Berikut ini dapat dilihat data pengguna internet di Provinsi Bali :

Tabel 1.

Data Pengguna Internet di Provinsi Bali

\begin{tabular}{cc}
\hline Kabupaten & Akses Internet (Persen) \\
\hline Jembrana & 33,99 \\
Tabanan & 41,18 \\
Badung & 61,18 \\
Gianyar & 47,44 \\
Klungkung & 38,29 \\
Bangli & 30,94 \\
Karangasem & 28,89 \\
Buleleng & 30,84 \\
Denpasar & 66,11 \\
\hline
\end{tabular}

Sumber : Data diolah, 2020

Salah satu bubble drink yang sudah tidak asing lagi di telinga masyarakat khusunya masyarakat Kota Denpasar adalah Chatime. Kurang lebih 230 gerai Chatime di Indonesia telah beroperasi hingga tahun 2018 (Indonesia, 2020). Berikut ini merupakan Tabel 2. top brand index kategori bubble drink dalam tiga tahun terakhir (2017-2019) : 
Tabel 2.

Top Brand For Teens Index 2019 Kategori Bubble Drink

\begin{tabular}{llll}
\hline Brand & \multicolumn{3}{c}{ TBI (Persen) } \\
\cline { 2 - 4 } & $\mathbf{2 0 1 7}$ & $\mathbf{2 0 1 8}$ & $\mathbf{2 0 1 9}$ \\
\hline Chatime & 22.50 & 44.88 & 56.00 \\
Hop-hop & 5.80 & 30.74 & 12.50 \\
Lup-lup & 3.20 & 6.31 & 11.90 \\
Chill Bubble Tea & - & - & 4.50 \\
Quickly & 46.60 & 2.01 & 3.10 \\
\hline
\end{tabular}

Sumber : Data diolah, 2019

Dari hasil pra survei yang dilakukan pada sepuluh orang yang ada di Kota Denpasar terdapat hasil sebagai berikut :

Tabel 3.

Hasil pra survei di Kota Denpasar

\begin{tabular}{llc}
\hline No. & Ya & Tidak \\
\hline $\begin{array}{l}\text { 1. Tahu tentang bubble drink merek Chatime } \\
\text { 2. Mampu membedakan bubble drink merek Chatime dengan }\end{array}$ & 10 & 0 \\
$\begin{array}{l}\text { merek lain yang sejenis. } \\
\text { 3. Pernah menerima informasi dari media sosial Chatime }\end{array}$ & 4 & 6 \\
4. $\begin{array}{l}\text { Chatime mampu menyampaikan informasi melalui media sosial } \\
\text { dengan bahasa yang baik dan benar }\end{array}$ & 4 & 6 \\
5. Media sosial Chatime membuat saya terdorong untuk membeli & 4 & 6 \\
$\begin{array}{l}\text { produk Chatime } \\
\text { Ingin segera membeli produk Chatime }\end{array}$ & 5 & 5 \\
\hline
\end{tabular}

Sumber : Data diolah, 2019

Pengaruh media massa, baik cetak dan elektronik sangat efektif memengaruhi niat calon pembeli untuk melakukan pembelian aktual terhadap produk, setelah konsumen merasa terangsang, konsumen akan terdorong untuk mencari informasi yang lebih banyak mengenai produk (Firmansyah, 2018:28). Media sosial sebagai alat atau cara yang dilakukan perusahaan atau konsumen untuk membagikan informasi berupa teks, gambar, video, dan audio kepada orang lain atau sebaliknya (Kotler \& Keller, 2016:642). Beberapa penelitian sebelumnya yang meneliti pengaruh social media marketing terhadap purchase intention. Hasil penelitian yang dilakukan Setiawan \& Aksari (2020) menemukan hasil bahwa brand awareness berpengaruh positif dan signifikan terhadap purchase intention karena suatu merek semakin dikenali, diingat, dan dijadikan pilihan utama oleh masyarakat akan meningkatkan purchase intention. Penelitian yang dilakukan Ashfaq et al. 2014 menghasilkan bahwa brand awareness berperan dalam hubungan social media marketing terhadap purchase intention karena pemasaran media sosial secara tidak langsung memengaruhi niat pembelian pelanggan. Penelitian yang dilakukan oleh Hutter et al. (2013) social media marketing berpengaruh positif dan signifikan terhadap purchase intention. Namun, sebaliknya 
penelitian yang dilakukan Soewandi (2015) menemukan hasil bahwa komunikasi media sosial memiliki hubungan negatif terhadap niat beli konsumen, apabila pengaruh dari dimensi ekuitas merek dihilangkan. Dimensi ekuitas merek yaitu brand awareness didominasi yang oleh simbol/logo. Jadi, semakin kuat simbol/logo perusahaan dikenali konsumen, dapat meningkatkan social media marketing perusahaan yang akan memengaruhi purchase intention.

Brand awareness penting dalam bisnis, konsumen biasanya akan membeli barang atau menggunakan jasa berdasarkan nama merek yang mudah dikenali dan sudah dipercaya, hal tersebut dapat mengakibakan merek yang pertama kali muncul di dalam benak konsumen, kemungkinan besar akan dibeli dan dipilih. Kesadaran merek dapat meningkatkan niat beli konsumen. Membangun brand awareness melalui media digital merupakan hal yang sangat penting dari sebuah merek karena media sosial dapat dijadikan tempat untuk berinteraksi dengan para konsumen dan calon konsumen . langsung (Oktaviani \& Rustandi, 2018)

Tujuan penelitian ini adalah untuk mengetahui pengaruh social medi marketing terhadap brand awareness; pengaruh social medi marketing terhadap purchase intention; pengaruh brand awareness terhadap purchase intention; dan peran brand awareness memediasi pengaruh social medi marketing terhadap purchase intention.

Perilaku konsumen adalah semua kegiatan, tindakan serta proses psikologis yang mendorong tindakan tersebut pada saat sebelum membeli (Arini \& Sudiksa, 2019). Niat untuk melakukan pembelian timbul setelah menerima stimulasi dari sesuatu yang dilihat dan disertai dengan perasaan senang terhadap barang tersebut, kemudian menimbulkan keinginan yang meyakinkan bahwa barang tersebut mempunyai manfaat terhadap individu (Pramesti \& Rahanatha, 2019)

Merek suatu produk yang sudah dikenal dapat membuat konsumen merasa aman karena dapat terhindar dari resiko yang dapat merugikan konsumen. Perusahaan perlu melakukan pendekatan kepada konsumen dalam upaya membentuk brand awareness di benak konsumennya, agar mudah mengenali merek suatu produk di antara merek lainnya (Upadana \& Pramudana, 2020). Brand awareness adalah kapasitas konsumen untuk mengenali sebuah merek di antara merek lain(Akhmedov, 2016)

Kotler \& Keller (2016:642) mendefinisikan media sosial sebagai alat atau cara yang dilakukan perusahaan atau konsumen untuk membagikan informasi berupa teks, gambar, video, dan audio kepada orang lain atau sebaliknya.

Penelitian sebelumnya yang dilakukan Ashfaq et al. (2014) social media marketing berpengaruh positif signifikan terhadap brand awareness. Penelitian serupa dilakukan Ratana (2018) juga mendapatkan hasil bahwa social media marketing berpengaruh positif signifikan terhadap brand awareness pada program crowdscourcing. Penelitian sebelumnya dari Stojanovic et al. (2018) mengatakan bahwa social media marketing berpengaruh positif dan signifikan terhadap brand awareness. Penelitian yang dilakukan Colicev et al. (2018) menemukan hasil yang sama bahwa media sosial berpengaruh positif pada brand awareness. Melihat kajian penelitian terdahulu maka dirumuskan hipotesis penelitian :

$\mathrm{H}_{1} \quad$ : Social Media Marketing berpengaruh positif dan signifikan terhadap Brand Awareness 
Penelitian yang dilakukan oleh Semuel \& Setiawan (2018) pada produk sepatu olahraga di Kota Surabaya hasilnya adalah promosi dengan social media marketing berpengaruh positif dan signifikan terhadap purchase intention. Penelitian serupa juga dilakukan oleh Hutter et al. (2013)social media marketing berpengaruh positif dan signifikan terhadap purchase intention dan penelitian dari Ashfaq et al. (2014) juga menemukan bahwa social media marketing berpengaruh positif dan signifikan terhadap purchase intention. Melihat kajian penelitian terdahulu maka dirumuskan hipotesis penelitian :

$\mathrm{H}_{2} \quad$ : Social Media Marketing berpengaruh positif dan signifikan terhadap

Purchase Intention

Penelitian sebelumnya yang dilakukan Wedayanti \& Ardani (2020) mendapatkan hasil bahwa brand awareness berpengaruh positif dan signifikan terhadap purchase intention. Penelitian Dewi \& Sulistyawati (2018) menyatakan bahwa brand awareness berpengaruh positif terhadap purchase intention (niat beli) produk pasta gigi Sensodyne di Kota Denpasar serta penelitian dari Setiawan \& Aksari (2020) mendapatkan hasil yang sama yaitu brand awareness berpengaruh positif dan signifiakan terhadapt purchase intention pada produk sepatu Adidas Yeezy. Melihat kajian penelitian terdahulu maka dirumuskan hipotesis penelitian : $\mathrm{H}_{3} \quad$ : Brand Awareness berpengaruh positif dan signifikan terhadap Purchase Intention

Penelitian yang dilakukan oleh Kusuma dkk. (2019) menghasilkan bahwa pengaruh dari social media marketing terhadap brand awareness adalah positif dan signifikan. Penelitian dari Setiawan \& Aksari (2020) menemukan hasil bahwa brand awareness berpengaruh positif dan signifikan terhadap purchase intention. Penelitian yang dilakukan oleh Ashfaq et al. (2014) menghasilkan bahwa brand awareness berperan dalam hubungan social media marketing terhadap purchase intention karena pemasaran media sosial tidak secara langsung mempengaruhi niat pembelian pelanggan. Melihat kajian penelitian terdahulu maka dirumuskan hipotesis penelitian :

$\mathrm{H}_{4} \quad$ : Brand Awareness memediasi secara signifikan pengaruh Social Media

Marketing terhadap Purchase Intention

Adapun kerangka konseptual dalam penelitian ini berdasarkan kajian pustaka dan penelitian sebelumnya adalah :

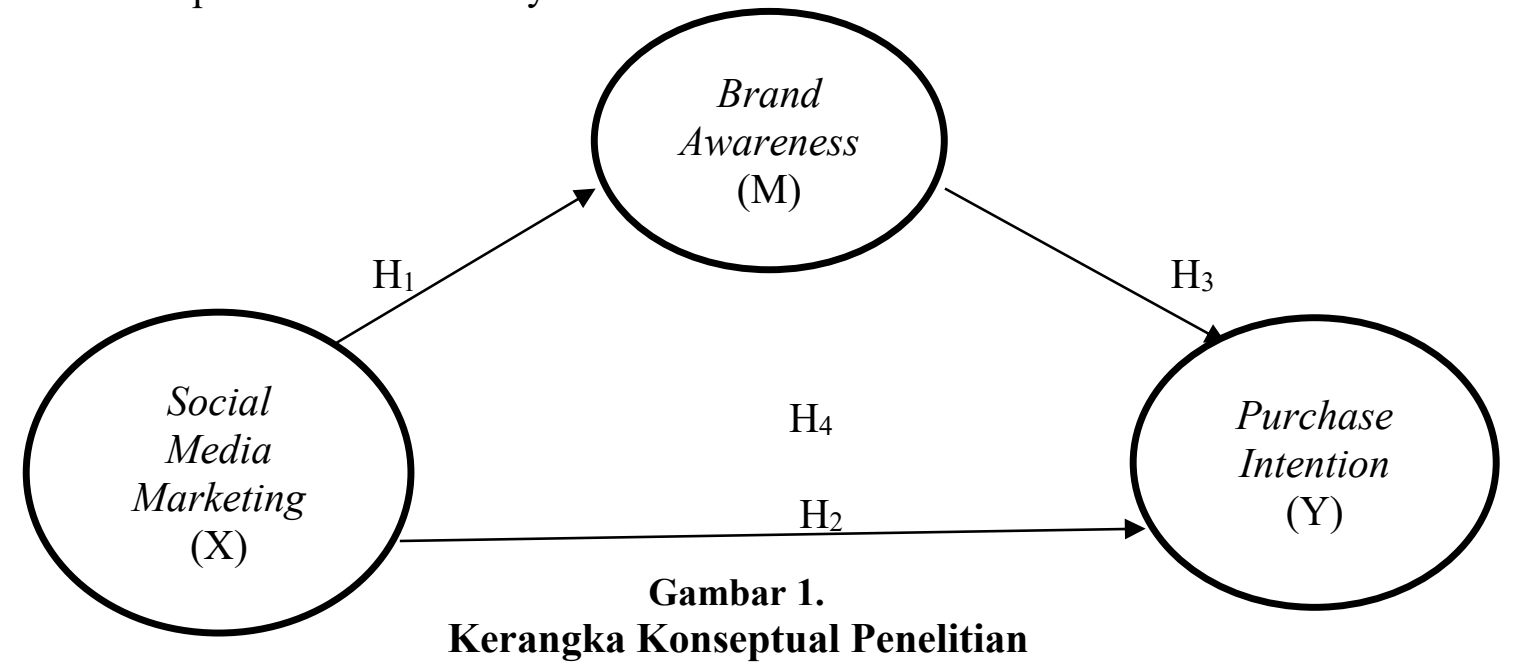




\section{METODE PENELITIAN}

Penelitian ini menggunakan pendekatan kuantitatif yang berbentuk asosiatif. Penelitian ini dilakukan di Kota Denpasar dengan pertimbangan Kota Denpasar merupakan Ibu Kota Provinsi Bali sehingga mobilitas penduduk cukup tinggi dan merupakan pusat pendidikan dan ekonomi. Obyek penelitian ini yaitu social media marketing, brand awareness, dan purchase intention pada konsumen yang belum pernah membeli produk Chatime di Kota Denpasar. Variabel bebas dalam penelitian ini adalah social media marketing, variabel pemediasi adalah brand awareness dan variabel terikat adalah purchase intention.

Social media marketing adalah suatu bentuk pemasaran dengan menggunakan media digital baik berupa teks, gambar, video, dan audio untuk menyebarkan informasi kepada konsumen. Indikator social media marketing berdasarakan penelitian dari Seo \& Park (2018), Godey et al. (2016) dan As'ad et al. (2014) yang disesuaikan dengan penelitian saat ini, yaitu : entertainment, interaction, trendiness, cuztomization dan word of mouth.

Brand awareness adalah kesadaran merek sampai sejauh mana konsumen dapat mengenali dan menyadari tentang keberadaan suatu merek untuk pertama kalinya dibandingkan dengan merek lain dalam kategori produk tetentu. Indikator brand awareness berdasarakan penelitian dari Utami \& Ekawati (2019), Shahrokh et al. (2012) dan Eliasari \& Sukaatmadja (2017) yang disesuaikan dengan penelitian saat ini, yaitu : pengetahuan merek, mudah diingat dan dapat dibedakan,

Purchase intention adalah suatu sikap ketertarikan konsumen terhadap produk baik berupa barang atau jasa yang sesuai dengan kebutuhan dan keinginannya. Indikator purchase intention berdasarakan penelitian dari Saputra \& Widagda (2020), Ibrahim et al. (2013) dan Semuel \& Setiawan (2018) yang disesuaikan dengan penelitian saat ini, yaitu : pengaruh sosial, Keunggulan relatif, Pencarian informasi dan Tertarik untuk mencoba produk

Tabel 4.

Indikator Variabel Penelitian

\begin{tabular}{cl}
\hline Variabel & \multicolumn{1}{c}{ Indikator } \\
\hline Social media marketing & 1. Entertainment $\left(\mathrm{X}_{1}\right)$ \\
$(\mathrm{X})$ & 2. Interaction $\left(\mathrm{X}_{2}\right)$ \\
& 3. Trendiness $\left(\mathrm{X}_{3}\right)$ \\
& 4. Customization $\left(\mathrm{X}_{4)}\right.$ \\
& 5. Word of mouth $\left(\mathrm{X}_{5}\right)$ \\
\hline Brand awareness & 1. Pengetahuan merek $\left(\mathrm{M}_{1}\right)$ \\
$(\mathrm{M})$ & 2. Mudah diingat $\left(\mathrm{M}_{2}\right)$ \\
& 3. Dapat dibedakan $\left(\mathrm{M}_{3}\right)$
\end{tabular}

Purchase intention

(Y)
1. Pengaruh Sosial $\left(\mathrm{Y}_{1}\right)$

2. Keunggulan relatif $\left(\mathrm{Y}_{2}\right)$

3. Pencarian informasi $\left(\mathrm{Y}_{3}\right)$

4. Tertarik untuk mencoba produk $\left(\mathrm{Y}_{4}\right)$

Sumber : Seo \& Park (2018); Godey et al. (2016); As'ad et at. (2014); Utami \& Ekawati (2019), Shahrokh et al. (2012); Eliasari \& Sukaatmaja (2017); Saputra \& Widadga (2020); Ibrahim et al. (2013); dan Semuel \& Setiawan (2018) 
Metode penentuan sampel yang digunakan pada penelitian adalah non probability sampling yaitu teknik purposive sampling. Metode pengumpulan data dengan melakukan survei menyebar kuisioner secara online dengan google.form menggunakan skala likert. Teknik analisis data dalam penelitian ini menggunakan analisis statistik deskriptif dan analisis statistik inferensial yaitu uji asumsi klasik, path analysis dan uji sobel.

\section{HASIL DAN PEMBAHASAN}

Chatime adalah penyedia minuman brewed tea asal Taiwan yang menghadirkan lebih dari 50 varian rasa. Chatime memiliki setidaknya 1.002 cabang di 26 negara. Pada tahun 2006, Chatime membuka gerai pertama di luar Taiwan, tepatnya di California, Amerika Serikat hingga tahun 2013 Chatime berekspansi lebih dari 25 negara, termasuk ke Indonesia. Sedikitnya 230 gerai Chatime di Indonesia telah beroperasi hingga tahun 2018. Di Indonesia, Chatime merupakan salah satu bisnis unit di bawah payung Kawan Lama Group yang telah hadir sejak tahun 2011. Chatime Indonesia hadir dengan enam kategori minuman yang dapat dinikmati oleh segala usia, terdiri dari Signature Milk Tea (sajian minuman milk tea favorit), Tea Presso (menu teh klasik terbaik), Smoothies (menu spesial ice blended), Tea RRIFIC (seri minuman teh hijau dan hitam yang penuh rasa), Coffee and Latte (sajian minuman brewed coffee segar), dan Mood Refresh (seri minuman sehat dan menyegarkan). Adapun proses penyajian minuman, Chatime menggunakan daun teh pilihan yang diolah menggunakan brewing machine terbaru. Mengadopsi konsep penyajian customized drink, pelanggan Chatime dapat menentukan sendiri jenis topping dan takaran gula serta es yang diinginkan. Chatime juga selalu berinovasi dengan menghadirkan menu terbaru. Inovasi Chatime juga dibubuhkan pada pembuatan konsep gerai terbaru bernama CHATIME ATEALIER. Merupakan konsep gerai yang lebih premium dengan menghidangkan minuman yang dibuat menggunakan mesin nitro sehingga sensasi rasa dan dingin yang dihasilkan lebih refreshing (Indonesia, 2020).

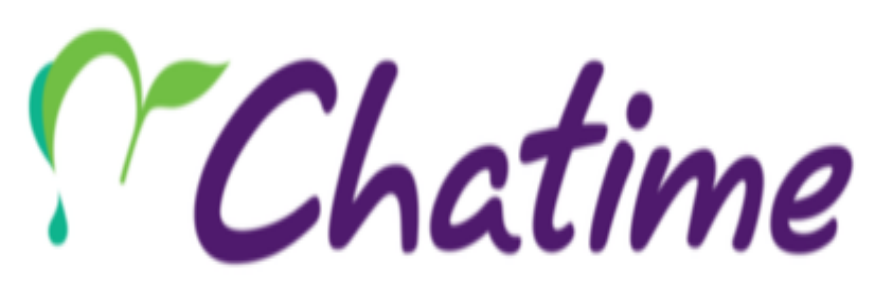

Gambar 2.

Logo Chatime

Sumber: (Indonesia, 2020) 
Data karakteristik responden adalah data responden yang dikumpulkan untuk mengetahui profil responden penelitian. Berdasarkan hasil penelitian yang dilakukan terhadap masyarakat Kota Denpasar yang belum pernah membeli produk Chatime dapat diketahui karakteristik respondennya meliputi jenis kelamin, usia, dan pekerjaan saat ini.

Tabel 5.

Karakteristik Responden pada Produk Chatime di Kota Denpasar

\begin{tabular}{|c|c|c|c|c|}
\hline No. & Variabel & Klasifikasi & Jumlah (orang) & Presentase (\%) \\
\hline \multirow[t]{4}{*}{1} & Usia & 17-20 Tahun & 19 & 15.8 \\
\hline & & 21-24 Tahun & 99 & 82.5 \\
\hline & & 25-28 Tahun & 2 & 1.7 \\
\hline & \multicolumn{2}{|c|}{ Jumlah } & 120 & 100 \\
\hline \multirow[t]{6}{*}{2} & Pekerjaan & Pelajar/Mahasiswa & 110 & 91.7 \\
\hline & & Aparatur Sipil Negara & 1 & 0.8 \\
\hline & & Pegawai Swasta & 1 & 0.8 \\
\hline & & Wiraswasta & 0 & 0 \\
\hline & & Lainnya & 8 & 6.7 \\
\hline & \multicolumn{2}{|c|}{ Jumlah } & 120 & 100 \\
\hline \multirow[t]{3}{*}{3} & Jenis Kelamin & Laki-laki & 44 & 36.7 \\
\hline & & Perempuan & 76 & 63.3 \\
\hline & \multicolumn{2}{|c|}{ Jumlah } & 120 & 100 \\
\hline
\end{tabular}

Sumber : Data diolah, 2020

Berdasarkan hasil penelitian 120 responden Kota Denpasar yang belum pernah membeli produk Chatime pada Tabel 5. Karakteristik responden berdasarkan usia, didominasi usia 21-24 tahun sebanyak 99 orang, berdasarkan pekerjaan didominasi pelajar/mahasiswa sebanyak 110 orang dan berdasarkan jenis kelamin didominasi perempuan sebanyak 76 orang.

Uji validitas dilakukan dengan mengkorelasikan antara skor faktor dengan skor total dan bila korelasi tiap faktor tersebut bernilai positif lebih besar dari 0,30 ( $\mathrm{r}>0,3)$ dengan tingkat kesalahan Alpha 0,50, maka instrumen penelitian tersebut dapat dikatakan valid. Instrumen dikatakan reliabel untuk mengukur variabel apabila memiliki nilai Cronbach Alpha $>0,60$.

Tabel 6.

Hasil Uji Validitas

\begin{tabular}{ccccc}
\hline No & Variabel & Item Pernyataan & $\begin{array}{c}\text { Pearson } \\
\text { Colleration }\end{array}$ & Keterangan \\
\hline 1 & Social Media & $\mathrm{X} 1$ & 0.592 & Valid \\
& Marketing & $\mathrm{X} 2$ & 0.832 & Valid \\
\hline
\end{tabular}

Bersambung... 
Lanjutan Tabel 6.

\begin{tabular}{ccccc}
\hline No & Variabel & Item Pernyataan & $\begin{array}{c}\text { Pearson } \\
\text { Colleration }\end{array}$ & Keterangan \\
\hline & & X3 & 0.911 & Valid \\
& X4 & 0.815 & Valid \\
& & X5 & 0.899 & Valid \\
\hline 2 & Brand Awareness & M1 & 0.721 & Valid \\
\hline \multirow{3}{*}{3} & M2 & 0.782 & Valid \\
& & M3 & 0.863 & Valid \\
\hline & & Y1 & 0.837 & Valid \\
& & Y2 & 0.882 & Valid \\
& & Y3 & 0.699 & Valid \\
& & Y4 & 0.759 & Valid \\
\hline
\end{tabular}

Sumber : Data diolah, 2020

Tabel 6. menunjukkan bahwa seluruh instrumen penelitian yang digunakan untuk mengukur variabel social media marketing, brand awareness dan purchase intention memiliki nilai pearson colleration dengan skor total seluruh item pernyataan nilainya lebih besar dari $0,30(\mathrm{r}>0,3)$ dengan signifikansi kurang dari 0,05 .

Tabel 7.

Hasil Uji Reliabilitas

\begin{tabular}{cccc}
\hline No & Variabel & Cronbach's Alpha & Keterangan \\
\hline 1 & Social Media Marketing $(\mathrm{X})$ & 0.868 & Reliabel \\
2 & Brand Awareness $(\mathrm{M})$ & 0.679 & Reliabel \\
3 & Purchase Intention $(\mathrm{Y})$ & 0.802 & Reliabel \\
\hline
\end{tabular}

Sumber : Data diolah, 2020

Tabel 7. menunjukkan nilai Cronbach's Alpha pada tiap variabel instrumen penelitian memiliki koefisien lebih besar dari 0,6 (Cronbach's Alpha >0,6). Hal ini berarti semua instrumen penelitian reliabel sehingga dapat digunakan untuk melakukan penelitian.

Uji asumsi klasik digunakan dengan tujuan untuk memastikan hasil yang diperoleh memenuhi asusmsi dasar di dalam analisis regresi. Hasil uji asumsi klasik yang dilakukan dalam penelitian ini adalah uji normalitas, uji multikolinieritas, uji heteroskedastisitas.

Tabel 8. menunjukan nilai Asymp. Sig. (2-tailed) pada struktur 1 sebesar 0,129 dan struktur 2 sebesar 0,150 . hal tersebut mengindikasikan bahwa modal persamaan regresi berdistribusi normal karena nilai Asymp. Sig. (2-tailed) lebih besar dari nilai Alpha 0,05 . 
Tabel 8.

Hasil Uji Normalitas

\begin{tabular}{|c|c|c|}
\hline & $\begin{array}{c}\text { Kolmogorov-Smirnov } Z \\
\text { Asymp. Sig.(2-tailed) }\end{array}$ & Unstandardized Residual \\
\hline \multirow[t]{3}{*}{$\mathrm{N}$} & & 120 \\
\hline & Struktur 1 & 0,129 \\
\hline & Struktur 2 & 0,150 \\
\hline
\end{tabular}

Tabel 9.

Hasil Uji Multikolinieritas

\begin{tabular}{ccc}
\hline Variabel & Tolerance & VIF \\
\hline Social Media Marketing & 0,453 & 2.207 \\
Brand Awareness & 0,454 & 2.207 \\
\hline
\end{tabular}

Sumber : Data diolah, 2020

Tabel 9. nilai tolerance dan VIF dari variabel social media marketing dan brand awareness menunjukan nilai tolerance untuk setiap variabel lebih besar dari sepuluh persen dan nilai VIF lebih kecil dari sepuluh yang berarti model persamaan regresi bebas dari multikolinieritas.

Tabel 10.

Hasil Uji Heteroskedastisitas

\begin{tabular}{cccc}
\hline Persamaan & Model & t & Sig. \\
\hline Struktur 1 & Social Media Marketing & -1.951 & .053 \\
& & & \\
Struktur 2 & Social Media Marketing & -.812 & .418 \\
& Brand Awareness & .197 & .844 \\
\hline
\end{tabular}

Sumber: Data diolah, 2020

Tabel 10. nilai signifikansi dari setiap variabel lebih besar dari 0,05 yang berarti tidak terdapat pengaruh antara variabel bebas/eksogen terhadap absolute residual sehingga model yang dibuat tidak mengandung gejala heteroskedastisitas.

Tabel 11.

Hasil Analisis Jalur Persamaan Regresi 1

\begin{tabular}{|c|c|c|c|c|c|c|}
\hline \multirow[b]{2}{*}{ Model } & & \multicolumn{2}{|c|}{$\begin{array}{c}\text { Unstandardized } \\
\text { Coefficients }\end{array}$} & \multirow{2}{*}{$\begin{array}{c}\text { Standardized } \\
\text { Coefficients }\end{array}$} & \multirow[b]{2}{*}{$\mathrm{t}$} & \multirow[b]{2}{*}{ Sig. } \\
\hline & & $\mathrm{B}$ & Std. Error & & & \\
\hline \multirow[t]{2}{*}{1} & (Constant) & 1.396 & 0.244 & & 5.732 & 0.000 \\
\hline & $\begin{array}{l}\text { Social Media } \\
\text { Marketing }\end{array}$ & 0.688 & 0.058 & 0.740 & 11.935 & 0.000 \\
\hline
\end{tabular}

Bersambung.... 
Lanjutan Tabel 11.

\begin{tabular}{|c|c|c|c|c|c|c|}
\hline \multirow{2}{*}{\multicolumn{2}{|c|}{ Model }} & \multicolumn{2}{|c|}{$\begin{array}{c}\text { Unstandardized } \\
\text { Coefficients }\end{array}$} & \multirow{2}{*}{$\begin{array}{c}\begin{array}{c}\text { Standardized } \\
\text { Coefficients }\end{array} \\
\text { Beta } \\
\end{array}$} & \multirow[b]{2}{*}{$\mathbf{t}$} & \multirow[b]{2}{*}{ Sig. } \\
\hline & & B & Std. Error & & & \\
\hline $\mathrm{R} 1^{2}$ & $: 0.547$ & & & & & \\
\hline F statistic & $: 142.450$ & & & & & \\
\hline Sig. F & $: 0.000$ & & & & & \\
\hline
\end{tabular}

Hasil analisi jalur persamaan regersi 1 seperti yang disajikan pada Tabel 11., maka persamaan strukturnya adalah sebagai berikut :

$$
\begin{gathered}
\mathrm{Y}_{1=} \beta_{1} \mathrm{X}+\mathrm{e}_{1} \ldots \ldots \ldots \ldots \ldots \ldots \ldots . .(1) \\
\mathrm{Y}_{1=0,740 \mathrm{X}}
\end{gathered}
$$

Nilai $\beta_{1}$ adalah sejumlah 0,740 memiliki social media marketing berpengaruh positif dan signifikan terhadap brand awareness, hal ini menunjukan bahwa apabila variabel social media marketing meningkat maka brand awareness produk Chatime di Kota Denpasar akan meningkat sebanyak 0,740. Besarnya pengaruh variabel bebas terhadap terikat yang ditunjukan oleh nilai determinasi total ( $R$ square) sebesar 0,547 mempunyai arti bawa sebesar 54,7 persen variasi brand awareness dipengaruhi oleh variasi social media marketing sedangkan sisanya sebesar 45,3 persen dijelaskaan oleh faktor lain yang tidak dimasukan ke dalam model.

Tabel 12.

\begin{tabular}{|c|c|c|c|c|c|c|}
\hline \multirow[b]{2}{*}{ Model } & & \multicolumn{2}{|c|}{$\begin{array}{c}\text { Unstandardized } \\
\text { Coefficients }\end{array}$} & \multirow{2}{*}{$\begin{array}{c}\begin{array}{c}\text { Standardized } \\
\text { Coefficients }\end{array} \\
\text { Beta } \\
\end{array}$} & \multirow[b]{2}{*}{$\mathrm{T}$} & \multirow[b]{2}{*}{ Sig. } \\
\hline & & $\mathrm{B}$ & Std. Error & & & \\
\hline \multirow[t]{3}{*}{1} & (Constant) & 0.516 & 0.273 & & 1.890 & 0.061 \\
\hline & $\begin{array}{l}\text { Social Media } \\
\text { Marketing }\end{array}$ & 0.406 & 0.085 & 0.413 & 4.770 & 0.000 \\
\hline & $\begin{array}{l}\text { Brand } \\
\text { Awareness }\end{array}$ & 0.443 & 0.091 & 0.420 & 4.847 & 0.000 \\
\hline $\mathrm{R} 1^{2}$ & 0.603 & & & & & \\
\hline F statistic & 88.765 & & & & & \\
\hline Sig. F & 0.000 & & & & & \\
\hline
\end{tabular}

Analisis Jalur Persamaan Regresi 2

Sumber : Data diolah, 2020

Hasil jalur persamaan regersi 2 pada Tabel 12. maka didapat persamaan struktural sebagai berikut :

$$
\mathrm{Y}_{2}=\beta_{2} \mathrm{X}+\beta_{3} \mathrm{Y}_{1}+\mathrm{e}_{2}
$$




$$
\mathrm{Y}=0.413 \mathrm{X}+0.420 \mathrm{Y}_{1}
$$

Nilai $\beta_{2}$ sejumlah 0,413 berarti social media marketing berpengaruh positif dan signifikan terhadap purchase intention, apabila variabel social media marketing meningkat maka variabel purchase intention produk Chatime di Kota Denpasar akan meningkat sebesar 0,413 . Nilai $\beta_{3}$ sejumlah 0,420 berarti brand awareness berpengaruh positif terhadap purchase intention, hal ini berarti apabila variabel brand awareness meningkat maka variabel purchase intention produk Chatime di Kota Denpasar akan meningkat sebesar 0,420. Besarnya pengaruh variabel bebas terhadap variabel terikat yang ditunjukan oleh nilai determinasi total ( $\mathrm{R}$ square) sebesar 0,603 mempunyai arti bahwa sebesar 60,3 persen variasi purchase intention dipengaruhi oleh variasi social media marketing dan brand awareness sedangkan sisanya sebesar 39,7 persen dijelaskan oleh faktor lain dalam model.

Berdasarkan model struktur 1 dan struktur 2 maka dapat disusun model diagram jalur akhir. Sebelum menyusun model diagram jalur akhir, terlebih dahulu dihitung standar error sebagai berikut :

$$
\begin{aligned}
& \mathrm{Pe}_{2}=\sqrt{1-R i^{2}} \ldots \ldots \ldots \ldots \ldots \ldots(3) \\
& \mathrm{Pe}_{1}=\sqrt{1-R i^{2}}=\sqrt{1-0,547}=\sqrt{0,453}=0,673 \\
& \mathrm{Pe}_{2}=\sqrt{1-R i^{2}}=\sqrt{1-0,603}=\sqrt{0,397}=0,630
\end{aligned}
$$

Hasil perhitungan error $\left(\mathrm{Pe}_{1}\right)$ maka hasil pengaruh error $\left(\mathrm{Pe}_{1}\right)$ yang didapat sebanyak 0,673 dan pengaruh error $\left(\mathrm{Pe}_{2}\right)$ sebanyak 0,630. Setelah menganalisi $\mathrm{e}_{1}$ dan $\mathrm{e}_{2}$, maka dapat didapat perhitungan koefisien determinasi total sebagai berikut:

$$
\begin{aligned}
\mathrm{R}^{2} \mathrm{~m} & =1-\left(\mathrm{Pe}_{1}\right)^{2}\left(\mathrm{Pe}_{2}\right)^{2} \ldots \ldots \\
& =1-(0,673)^{2}(0,630)^{2} \\
& =1-0,452 \times 0,396 \\
& =1-0,178 \\
& =0,822
\end{aligned}
$$

Nilai determinasi total sebesar 0,822 memiliki arti bahwa 82,2 persen variabel purchase intention dipengaruhi oleh variabel social media marketing dan brand awareness, sisanya sebesar 17,8 persen dijelaskan oleh faktor lain diluar model yang dibentuk.

Tabel 13. menunjukan bahwa social media marketing berpengaruh langsung terhadap purchase intention sebesar 0,413 dengan dimediasi oleh variabel brand awareness maka didapatkan pengaruh tidak langsung sebesar 0,310 dan pengaruh total sebesar 0,723 . Hasil tersebut menunjukan bahwa brand awareness memediasi pengaruh social media marketing terhadap purchase intention.

Uji sobel merupakan alat analisis untuk menguji signifikansi dari hubungan tidak langsung antara variabel independen dengan variabel dependen yang dimediasi oleh variabel mediasi. Bila nilai kalkulasi Z lebih besar dari 1,96 dengan tingkat kepercayaan 95 persen, maka variabel mediasi dinilai secara signifikan memediasi hubungan antara variabel independen dan variabel dependen. Uji sobel dihitung dengan rumus sebagai berikut. 
Tabel 13.

Pengaruh Langsung dan Pengaruh Tidak Langsung serta Pengaruh Total Social Media Marketing (X), Brand Awareness ( $\left.\mathrm{Y}_{1}\right)$ dan Purchase Intention $\left(\mathbf{Y}_{2}\right)$

\begin{tabular}{cccc}
\hline $\begin{array}{c}\text { Pengaruh } \\
\text { Variabel }\end{array}$ & $\begin{array}{c}\text { Pengaruh } \\
\text { Langsung }\end{array}$ & $\begin{array}{c}\text { Pengaruh Tidak Langsung } \\
\text { Melalui Brand Awareness }\end{array}$ & $\begin{array}{c}\text { Pengaruh } \\
\text { Total }\end{array}$ \\
\hline $\mathrm{X} \rightarrow \mathrm{Y}_{1}$ & 0,740 & $\mathbf{( Y 1 ) ( \boldsymbol { \beta 1 } \mathbf { x } \boldsymbol { \beta } 2 )}$ & \\
$\mathrm{X} \rightarrow \mathrm{Y}_{2}$ & 0,413 & - & 0,740 \\
$\mathrm{Y}_{1} \rightarrow \mathrm{Y}_{2}$ & 0,420 & 0,310 & 0,723 \\
\hline Pumber & & - & 0,420 \\
\hline
\end{tabular}

Sumber : Data diolah, 2020

$$
Z=\frac{a b}{\sqrt{a^{2} S_{b}^{2}+b^{2} S_{a}^{2}+S_{a}^{2} S_{b}^{2}}}
$$

Keterangan :

$$
\begin{aligned}
& \mathrm{a}=0,688 \\
& \mathrm{~S}_{\mathrm{a}}=0,058 \\
& \mathrm{~b}=0,443 \\
& \mathrm{~S}_{\mathrm{b}}=0,091 \\
& \mathrm{p}=0,000 \\
& \mathrm{Z} \quad=\frac{0,688 \times 0,443}{\sqrt{\left(0,443^{2} 0,091^{2}\right)+\left(0,443^{2} 0,058^{2}\right)+\left(0,058^{2} 0,091^{2}\right)}} \\
& =\frac{0,3048}{\sqrt{0,0039+0,0007+0.0000}} \\
& =\frac{0,3048}{\sqrt{0,0046}} \\
& =\frac{0,3048}{0,067881} \\
& =4,490
\end{aligned}
$$

Hasil perhitugan menunjukan nilai $\mathrm{Z}$ hitung sebesar 4,490 > 1,96 dengan nilai signifikansi (p) sebesar $0,000<0,05$ yang artinya brand awareness merupakan variabel yang memediasi pengaruh social media marketing terhadap purchase intention pada produk Chatime di Kota Denpasar atau dengan kata lain social media marketing berpengaruh tidak langsung terhadap purchase intention melalui brand awareness.

Hasil penelitian ini menunjukan bahwa social media marketing berpengaruh positif dan signifikan terhadap brand awareness. Apabila social media marketing meningkat maka berdampak pada peningkatan brand awareness. Indikator social media marketing yang mendominasi pada penelitian ini adalah "dapat menyediakan berita terbaru" dan "adanya interaksi orang dengan orang lain secara online". Hal ini berarti bahwa semakin up to date berita yang disediakan oleh social media dan semakin luas ruang yang disediakan untuk konsumen berinteraksi secara online 
maka dapat mempengaruhi brand awareness.

Hal ini didukung oleh penelitian Setiawan \& Yosanova (2016) social media marketing merupakan bentuk pemasaran yang dipakai untuk menciptakan kesadaran, pengakuan, ingatan dan bahkan tindakan terhadap suatu merek, produk, bisnis, individu, atau kelompok baik secara langsung maupun tidak langsung dengan menggunakan alat dari web sosial seperti blogging, microblogging, dan jejaring sosial dan Kshetri \& Jha (2016) yang menyatakan penggunaan media sosial terhadap suatu brand merupakan suatu komunikasi yang menyampaikan informasi mengenai penggunaan produk kepada konsumen melalui online shopping menggunakan teknologi berbasis internet seperti LINE, facebook, instagram, dan berbagai media sosial lainnya.

Hasil penelitian ini sesuai dengan penelitian Ashfaq et al. (2014) social media marketing berpengaruh positif signifikan terhadap brand awareness karena setiap aktivitas yang dilakukan pada penggunaan media sosial meningkatkan kesadaraan merek. Penelitian serupa dilakukan oleh (Ratana, 2018) juga mendapatkan hasil bahwa social media marketing berpengaruh positif signifikan terhadap brand awareness pada program crowdscourcing karena social media dapat digunakan untuk menciptakan kesan yang kuat dan membekas dalam benak masyarakat tentang sebuah brand. Penelitian sebelumnya dari Stojanovic et al. (2018) dan Colicev et al. (2018) mengatakan bahwa social media marketing berpengaruh positif dan signifikan terhadap brand awareness, apabila social media marketing tinggi, maka akan berdampak pada peningkatkan brand awareness dibenak konsumen.

Hasil penelitian ini menunjukan bahwa social media marketing berpengaruh positif dan signifikan terhadap purchase intention. Apabila social media marketing meningkat maka berdampak pada peningkatan purchase intention. Indikator social media marketing yang mendominasi pada penelitian ini adalah "dapat menyediakan berita terbaru" dan "adanya interaksi orang dengan orang lain secara online". Hal ini berarti bahwa semakin up to date berita yang disediakan oleh social media dan semakin luas ruang yang disediakan untuk konsumen berinteraksi secara online maka dapat mempengaruhi niat beli (purchase intention).

Hasil penelitian ini sesuai dengan penelitian Semuel \& Setiawan (2018) pada produk sepatu olahraga di Kota Surabaya hasilnya adalah promosi dengan social media marketing berpengaruh positif dan signifikan terhadap purchase intention karena promosi melalui media sosial dapat memberikan pengaruh kepada minat beli dari konsumen, hal ini memperlihatkan bahwa promosi dari sebuah produk mampu mempengaruhi minat beli seorang konsumen pada sebuah produk sepatu olahraga. Penelitian serupa juga dilakukan oleh Hutter et al. (2013) social media marketing berpengaruh positif dan signifikan terhadap purchase intention dan penelitian yang dilakukan oleh Ashfaq et al. (2014) juga menemukan bahwa social media marketing berpengaruh positif dan signifikan terhadap purchase intention karena informasi yang kumpulkan dari situs media sosial memotivasi konsumen untuk melakukan pembelian.

Hasil social media marketing yang mendapat penilaian paling rendah adalah "dapat memberikan suatu hiburan". Melihat fenomena tersebut, berarti secara umum konsumen belum menganggap social media marketing dapat 
memberikannya suatu hiburan. Menurut Kotler \& Keller (2016:532) untuk meningkatkan nilai hiburan beberapa perusahaan menggunakan avatar yaitu karakter animasi yang bertindak sebagai perwakilan perusahaan, asisten belanja pribadi, panduan situs web, atau mitra percakapan. Avatar dapat meningkatkan keefektifan saluran penjualan online, terutama jika dianggap ahli atau menarik. Hal yang harus dilakukan pihak Chatime untuk meningkatkan hiburan bagi konsumen adalah dengan menambah fitur avatar di perusahaan seperti : customer service, pencarian informasi dan cara pemesanan. Pihak Chatime juga dapat memberikan hiburan bagi konsumen dengan mengadakan giveaway, quiz, voucher, fun fact dan bintang iklan.

Hasil penelitian ini menunjukkan bahwa brand awareness berpengaruh positif dan signifikan terhadap purchase intention. Apabila brand awareness meningkat maka berdampak pada peningkatan purchase intention. Indikator brand awareness yang mendominasi pada penelitian ini adalah "mampu membedakan merek Chatime dengan merek lainnya". Hal ini berarti bahwa semakin tinggi kesadaran merek terhadap suatu produk maka, semakin kuat merek diingatan konsumen. Selain itu, logo merek yang menarik dan unik juga dapat memudahkan konsumen untuk membedakan merek dengan merek lainnya, yang dapat memengaruhi purchase intention.

Hasil penelitian ini sesuai dengan penelitian Wedayanti \& Ardani (2020) dan Dewi \& Sulistyawati (2018) mendapatkan hasil bahwa brand awareness berpengaruh positif dan signifikan terhadap purchase intention, apabila brand awareness produk meningkat, maka akan meningkatkan niat beli pada konsumen terhadap produk, serta penelitian Setiawan \& Aksari (2020) mendapatkan hasil yang sama yaitu brand awareness berpengaruh positif dan signifiakan terhadap purchase intention karena merek yang semakin dikenali, diingat, dan dijadikan pilihan utama oleh masyarakat akan meningkatkan purchase intention pada sepatu Adidas Yeezy

Hasil penelitian ini menunjukan bahwa peran brand awareness mampu memediasi hubungan antara variabel social media marketing terhadap purchase intention pada produk Chatime di Kota Denpasar atau dengan kata lain social media marketing berpengaruh tidak langsung terhadap purchase intention melalui brand awareness karena diakibatkan oleh indikator brand awareness yg didominasi oleh "mampu membedakan merek Chatime dengan merek lainnya". Hal ini berarti bahwa semakin kuat brand awareness, maka berdampak pada hubungan social media marketing terhadap purchase intention. Melihat fenomena tersebut, perusahaan harus mampu meningkatkan brand awareness bagi konsumen karena akan berdampak pada peningkatan interaksi social media marketing perusahaan sehingga akan mempengaruhi niat melakukan pembelian.

Hasil penelitian ini sesuai dengan penelitian Kusuma dkk. (2019) menghasilkan bahwa pengaruh dari social media marketing terhadap brand awareness adalah positif dan signifikan. Penelitian Setiawan \& Aksari (2020) menemukan hasil bahwa brand awareness berpengaruh positif dan signifikan terhadap purchase intention karena suatu merek semakin dikenali, diingat, dan dijadikan pilihan utama oleh masyarakat akan meningkatkan purchase intention. Penelitian yang dilakukan Ashfaq et al. (2014) menghasilkan bahwa brand 
awareness berperan dalam hubungan social media marketing terhadap purchase intention karena pemasaran media sosial secara tidak langsung mempengaruhi niat pembelian pelanggan. Niat pembelian pelanggan meningkat ketika perusahaan peduli terhadap merek mereka sehingga pelanggan menjadi terlibat secara emosional dengan merek.

Jadi, berdasarkan uraian tersebut berarti Chatime memang berbeda di bandingkan dengan produk yang lainnya, sehingga hal tersebut membuat brand awareness mampu memediasi secara signifikan hubungan antara social media marketing terhadap purchase intention

Implikasi praktis bagi perusahaan, social media marketing yang dikemas dengan menarik baik berupa gambar, animasi, tulisan, bahasa maupun fitur-fitur menarik dan informasi yang up to date dapat membuat konsumen percaya dan menimbulkan niat untuk membeli produk yang ditawarkan. Social media marketing dapat dijadikan wadah untuk berinteraksi dengan konsumen secara online dan dapat menyediakan suatu hiburan bagi konsumen. Suatu merek yang dapat dikenali dan diingat oleh konsumen dapat menjadi alternatif pilihan bagi konsumen ketika melakukan pembelian suatu produk. Penggunaan logo yang menarik dan unik/memiliki ciri khas tersendiri dapat meningkatkan brand awareness sehingga menimbukan niat beli.

\section{SIMPULAN}

Social media marketing berpengaruh positif dan signifikan terhadap purchase intention. Hal ini menunjukan bahwa pemasaran dengan social media yang menarik dapat meningkatkan niat beli terhadap suatu produk. Social media marketing berpengaruh positif dan signifikan terhadap brand awareness. Hal ini menunjukan bahwa semakin baik dan menarik pemasaran yang dilakukan dengan social media maka kesadaran merek juga semakin tinggi. Brand awareness berpengaruh positif dan signifikan terhadap purchase intention. Hal ini menunjukan bahwa semakin tinggi kesadaran merek konsumen terhadap suatu produk maka semakin tinggi juga niat beli. Brand awareness memediasi pengaruh social media marketing terhadap purchase intention. Hal ini menunjukan bahwa brand awareness dapat memberikan dampak yang signifikan dan dapat meningkatkan pengaruh social media marketing dengan purchase intention.

Sebaiknya hal yang perlu dilakukan pihak Chatime terkait social media marketing adalah sebaiknya pihak Chatime menambah fitur avatar di perusahaan untuk meningkatkan nilai hiburan seperti : customer service, pencarian informasi dan cara pemesanan. Pihak Chatime juga dapat memberikan hiburan bagi konsumen dengan mengadakan giveaway, quiz, voucher, fun fact dan bintang iklan. Hal yang harus dilakukan terkait dengan brand awareness adalah pihak Chatime sebaiknya membuat iklan informatif seperti : informasi mengenai produk, ketersediaan produk, perubahan harga, varian menu, dan lokasi gerai Chatime untuk meningkatkan pengetahuan konsumen terhadap produk Chatime dan hal yang harus dilakukan oleh pihak Chatime terkait dengan purchase intention adalah sebaiknya pihak Chatime meningkatkan informasi yang diberikan kepada konsumen dengan memberikan informasi yang unik mengenai produk, seperti : iklan yang menarik 
dengan pengunaan animasi, karakter, musik, dan gambar maupun font yang unik.

\section{REFERENSI}

Akhmedov, R. (2016). Social Networking to Expand Brand Awareness and Influence on Purchase Intention. Journal of Suleyman Demirel University, $8(2), 311-317$.

Arini, P. E., \& Sudiksa, I. B. (2019). Peran Persepsi Harga Dalam Memediasi Brand Image Terhadap Niat Beli Konsumen. E-Jurnal Manajemen Unud, 8(3), 1665-1695.

https://doi.org/https://doi.org/10.24843/EJMUNUD.2019.v8.i3.p18

As'ad, Abu-Rumman, H., \& Alhadid, A. Y. (2014). The Impact of Social Media Marketing on Brand Equity: An Empirical Study on Mobile Service Providers in Jordan. Review of Integrative Business \& Economics Research, 3(1), 315326.

Ashfaq, Ahmed, M., \& Zahid, Z. (2014). Role of social media marketing to enhance $\mathrm{CRM}$ and brand equity in terms of purchase intention. Anticancer Research, 21(3 B), 2229-3795.

Colicev, A., Malshe, A., \& Pauwels, K. (2018). Social Media and Customer-Based Brand Equity: An Empirical Investigation in Retail Industry. Administrative Sciences, 8(3), 55. https://doi.org/https://doi.org/10.3390/admsci8030055

Denpasar, P. K. (2019). Profil Kota Denpasar. Retrieved April 23, 2020, from https://denpasarkota.go.id

Dewi, V. C., \& Sulistyawati, E. (2018). Peran Brand Awareness Memediasi Pengaruh Iklan Terhadap Niat Beli (Studi Pada Produk Pasta Gigi Merek Sensodyne Di Kota Denpasar). E-Jurnal Manajemen Unud, 7(4), 1742-1770. https://doi.org/https://doi.org/10.24843/ejmunud.2018.v07.i04.p02

Eliasari, P. R. A. E., \& Sukaatmadja, I. P. G. (2017). Pengaruh Brand Awareness Terhadap Purchase Intention Dimediasi Oleh Perceived Quality Dan Brand Loyalty. E-Jurnal Manajemen Unud, 6(12), 6620-6650.

Firdausya, A. (2019). Bubble Tea vs Pepsi: Rise and Fall, then Rise again or Fall instead? Retrieved December 3, 2020, from Yonulis website: https://yonulis.com/2019/10/09/bubble-tea-vs-pepsi-rise-and-fall-then-riseagain-or-fall-instead/

Firmansyah, M. A. (2018). Perilaku Konsumen (Sikap dan Pemasaran). Yogyakarta: Deepublish.

Godey, B., Manthiou, A., Pederzoli, D., Rokka, J., Aiello, G., Donvito, R., \& Singh, 
R. (2016). Social media marketing efforts of luxury brands: Influence on brand equity and consumer behavior. Journal of Business Research, 69(12), 58335841. https://doi.org/10.1016/j.jbusres.2016.04.181

Hutter, K., Hautz, J., Dennhardt, S., \& Füller, J. (2013). The impact of user interactions in social media on brand awareness and purchase intention: the case of MINI on Facebook. Journal of Product \& Brand Management., 22(5/6), 342 - 351. Retrieved from http://dx.doi.org/10.1108/JPBM-05-2013$\% 090299$

Ibrahim, I. I., Subari, K. A., Kassim, K. M., \& Mohamood, S. K. B. (2013). Antecedent Stirring Purchase Intention of Smartphone among Adolescents in Perlis. International Journal of Academic Research in Business and Social Sciences, 3(12), 84-97. https://doi.org/10.6007/ijarbss/v3-i12/415

Indonesia, C. (2020). Tentang Chatime Indonesia. Retrieved April 23, 2020, from https://indonesia.chatime.com.tw/

Kotler, P., \& Keller, K. L. (2016). Marketing Management. 15th Edition (P. E. Limited., Ed.). London.

Kshetri, A., \& Jha, B. (2016). Online Purchase Intention: A Study of Automobile Sector in India. Review of Integrative Business and Economics, 5(3), 35-59. Retrieved from http://buscompress.com/journal-home.html

Kusuma, B. A., Primadani, B., \& Putri, S. (2019). Pengaruh Social Media Marketing Terhadap Brand Equity. JIM UPB, 7(1), 33-37.

Oktaviani, F. \&, \& Rustandi, D. (2018). Implementasi Digital Marketing dalam Membangun Brand Awareness. PRofesi Humas, 3(1), 1-20. https://doi.org/https://doi.org/10.24198/prh

Pramesti, I.A.C., \& Rahanatha, G. . (2019). Peran Brand Image Memediasi Pengaruh Word Of Mouth ( Wom ) Terhadap Niat Beli Konsumen. E-Jurnal Manajemen Universitas Udayana, 8(1), 7073-7101. https://doi.org/https://doi.org/10.24843/EJMUNUD.2019.v8.i1.p5

Ratana, M. (2018). Pengaruh Social Media Marketing Terhadap Ekuitas Merek. Jurnal Studi Komunikasi Dan Media, 22(1), 13. https://doi.org/10.31445/jskm.2018.220102

Saputra, I. K. A., \& Widagda, I. G. N. J. A. (2020). Brand Image, Product Knowledge, Dan Electronic Word Of Mouthberpengaruh Terhadap Purchase Intention. E-Jurnal Manajemen Unud, 45(Supplement), S-102. https://doi.org/https://doi.org/10.24843/EJMUNUD.2020.v09.i03.p16 
Semuel, H., \& Setiawan, K. Y. (2018). Promosi Melalui Sosial Media, Brand Awareness, Purchase Intention Pada Produk Sepatu Olahraga. Manajemen Pemasaran, 12(1), 47-52. https://doi.org/10.9744/pemasaran.12.1.47

Seo, E. J., \& Park, J. W. (2018). A study on the effects of social media marketing activities on brand equity and customer response in the airline industry. Journal of Air Transport Management, 66, 36-41. https://doi.org/https://doi.org/10.1016/j.jairtraman.2017.09.014

Setiawan, I., \& Yosanova, S. (2016). "New Content Marketing” Gaya Baru Pemasaran Era Digita. Jakarta: PT. Gramedia Pustaka Utama.

Setiawan, I. B. P. A., \& Aksari, N. M. A. (2020). Peran Brand Awareness Dalam Memediasi Pengaruh Celebrity Endorser Terhadap Purchase Intention. EJurnal Manajemen Unud, 9(6), 2352-2373. https://doi.org/https://doi.org/10.24843/EJMUNUD.2020.v09.i06.p15

Shahrokh, Z. D., Sedghiani, J. S., \& Ghasemi, V. (2012). Analyzing the influence of customer attitude toward brand extension on attitude toward parent brand. Interdisciplinary Journal of Contemporary Research in Business, 3(9), 11331149. Retrieved from http://www.journal-archieves14.webs.com/11331148.pdf

Soewandi, M. (2015). The Impact of Social Media Marketing on Brand Equity toward the Purchase Intention of Starbucks Indonesia. IBuss Management, 3(2), 77-88.

Statistika, P. K. D. D. K. I. (2019). Denpasar Raih Penghargaan Best City Smart Economy 2019. Retrieved April 23, 2020, from https://kominfostatistik.denpasarkota.go.id

Stojanovic, I., Andreu, L., \& Curras, P. R. (2018). Effects of the intensity of use of social media on brand equity: An empirical study in a tourist destination. European Journal of Management and Business Economics, 27(1), 83-100. https://doi.org/https://doi.org/10.1108/EJMBE-11-2017-0049

Upadana, M. W. K., \& Pramudana, K. A. S. (2020). Brand Awareness Memediasi Pengaruh Social Media Marketing Terhadap Keputusan Pembelian. E-Jurnal Manajemen Unud, 9(5), 1921-1941. https://doi.org/https://doi.org/10.24843/EJMUNUD.2020.v09.i05.p14

Utami, N. K. D., \& Ekawati, N. W. (2019). Pengaruh Daya Tarik Iklan Terhadap Brand Attitude Melalui Brand Awareness Sebagai Variabel Mediasi. E-Jurnal Manajemen Unud, 8(10), 5947-5965. https://doi.org/https://doi.org/10.24843/EJMUNUD.2019.v08.i10.p04 
Ni Made Ayu Sutariningsih, Peran Brand Awareness...

Wedayanti, K. A., \& Ardani, I. G. A. K. S. (2020). Peran Brand Image Memediasi Pengaruh Electronic Word Of Mouth dan Brand Awareness Terhadap Niat Beli. E-Jurnal Manajemen Unud, 9(6), 2434-2454. https://doi.org/https://doi.org/10.24843/EJMUNUD.2020.v09.i06.p19 